Makarnalık Buğday (Triticum durum Desf.) B27 × Ege 88 Resiprokal Melez Popülasyonunda $\mathrm{F}_{4}$ Kuşağının Allele Özgü Markörlerle Değerlendirilmesi

\author{
Merve BÜYÜKAKKAŞLAR ${ }^{1}$, İlker YÜCE² ${ }^{2}$, Tuğba BAŞKONUŞ³ ${ }^{3}$ Tevrican DOKUYUCU ${ }^{4}$, Aydın AKKAYA ${ }^{5}$ \\ Ziya DUMLUPINAR ${ }^{6}$

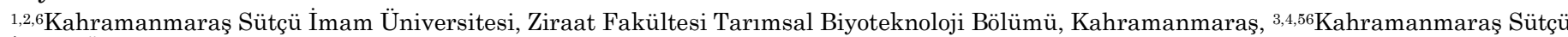 \\ İmam Üniversitesi Ziraat Fakültesi Tarla Bitkileri Bölümü, Kahramanmaraş, Türkiye \\ ${ }^{1}$ https://orcid.org/0000-0002-2150-3315, ${ }^{2}$ https://orcid.org/0000-0002-9761-3561, ${ }^{3}$ https://orcid.org/0000-0002-0744-6086 \\ ${ }^{4} \mathrm{https}: / /$ orcid.org/0000-0002-7704-6790, ${ }^{5} \mathrm{https} / / / o r c i d . o r g / 0000-0001-9560-1922,{ }^{6} \mathrm{https}: / / o r c i d . o r g / 0000-0003-3119-6926$ \\ $\varangle$ : zdumlupinar@ksu.edu.tr
}

\section{ÖZET}

Makarnalık buğday ıslah çalışmalarında kalite verim ve hastalıklara dayanıklılık önemli ıslah hedefleridir. Bu çalışmada, Türkiye'de belli bir ekim alanına sahip Ege 88 çeşidi ile bazı hastalık ve kalite özellikleri bakımından iyi olduğu bilinen B27 yerel makarnalık buğday çeşidinin resiproklu olarak melezlenmesiyle elde edilen ve $\mathrm{F}_{4}$ döl kuşağına getirilen, ebeveynlerle beraber toplam 39 genotip, mumsuluk ( $\left.W_{x}-A 1\right)$, kara pas $(S r 49)$, gluten mukavemeti (Glu-B1), yüksek protein oranı $(G p c-B 1)$, çavdar translokasyonu (1AL.1RS), vernelizasyon $(V r n-A 1)$ ve bin dane ağırlı̆̆ özelliklerine ait allel spesifik markörler ile karakterize edilmiştir. Araştırmada kullanılan 39 makarnalık buğday genotipi sekiz allel spesifik DNA primeri ile taranmış ve 56 adet polimorfik bant elde edilmiş ve bu data kullanılarak genotiplerin genetik mesafeleri belirlenmiştir. Ortalama bant sayısı 7 olarak bulunurken, en çok bant üreten markör 15 bant ile Sun 479, en az bant üreten markör bir bant ile $\mathrm{Bx}^{70 \mathrm{OE}}$ markörü olmuştur. Ortalama polimorfizm bilgi içeriği (PIC) değeri 0.875 olarak hesaplanmıştır. En yüksek PIC değeri 0.99 ile SUN1, SUN479, Bx ${ }^{70 E}$, RIS ve VRN1 markörlerinden, en düşük PIC değeri ise 0.39 ile UHW89 marköründen elde edilmiştir. Elde edilen markör verileri ile oluşturulan dendrograma göre, Ege $88 \times$ B27_3 genotipinin diğerlerinden genetik olarak uzak olduğu ve Ege $88 \times$ B27_7- Ege 88 $\times$ B27_8 ve B27 × Ege 88_5 - B27 × Ege 88_6 genotipleri ise \% 100 benzer bulunmuştur. Makarnalık buğday genotiplerinde mumsuluk $\left(W_{\boldsymbol{X}}-A 1\right)$, kara pas $(S r 49)$, yüksek protein oranı $(G p c-B 1)$, gluten mukavemeti $(G l u-B 1)$ ve çavdar translokasyonları (1AL.1RS) ile ilgili alleller tespit edilirken, vernelizasyon ( $V r n-A 1)$ ve bin tane ağırlığı ile ilgili beklenen uzunluklarda bant elde edilememiştir.
Araşturma Makalesi

Makale Tarihçesi
Geliş Tarihi $\quad: 01.05 .2020$
Kabul Tarihi $\quad: 11.06 .2020$

Anahtar Kelimeler

Makarnalık buğday

Resiprokal melez

Yerel çeşit

Kara pas

Gluten mukavemeti

\title{
Evaluation of $\mathrm{F}_{4}$ Individuals Obtained from B27 $\times$ Ege 88 Durum Wheat (Triticum durum Desf.)
} Reciprocal Cross Population by Allele Specific Markers

\section{ABSTRACT}

Yield, quality and disease resistance are important variables in durum wheat breeding studies. In this study, durum wheat cultivar Ege 88 which have been grown in a certain area in our country and durum wheat landrace B27 which is known as diseases tolerant with high quality properties were crossed as reciprocal and $39 \mathrm{~F}_{4}$ individuals with their parents were screened with allele specific markers for waxiness $\left(W_{x}-A 1\right)$, stem rust $(S r 49)$, gluten strength $\left(G l u^{-}\right.$ $B 1)$, high protein ratio $(G p c-B 1)$, rye translocation (1AL.1RS), vernalisation ( $V r n-A 1)$ and thousand kernel weight. In the research, 39 genotypes were screened with eight allele specific markers and produced 56 polymorphic bands and genetic distance of the genotypes were determined. The average allele number was determined as 7 , while the most allelic marker was Sun479 with 15 bands and the lowest allele number was obtained from $\mathrm{Bx}^{7 \mathrm{OE}}$ with only one allele.

\section{Research Article}

$\begin{array}{ll}\text { Article History } & \\ \text { Received } & : 01.05 .2020 \\ \text { Accepted } & : 01.06 .2020\end{array}$

\section{Keywords}

Reciprocal cross

Durum wheat

Landrace

Stem rust

Gluten strength 
The average polymorphism information content (PIC) was calculated as 0.875 . The highest PIC value was obtained from SUN1, SUN479, $\mathrm{Bx} 7^{\mathrm{OE}}$, RIS and VRN1 markers as 0.99 , while the lowest value was calculated as 0.39 from the UHW89 marker. According to the dendrogram created by the marker data Ege $88 \times$ B27_3 genotype was the most diverse one and Ege $88 \times$ B27_7- Ege $88 \times$ B27_8 and B27 $\times$ Ege 88_5- B27 $\times$ Ege 88_6 genotypes were found 100\% identical. The alleles for waxiness $\left(W_{x}-A 1\right)$, stem rust $(S r 49)$, high protein ratio $(G p c$ $B 1)$, gluten strength $(G l u-B 1)$ and rye translocation (1AL.1RS) were found on durum wheat genotypes, while the alleles for vernalisation (Vrn-A1) and thousand kernel weight were not identified.

To Cite : Büyükakkaşlar M, Yüce İ, Başkonuş T, Dokuyucu T, Akkaya A, Dumlupınar Z 2020. Makarnalık Buğday (Triticum durum Desf.) B27 × Ege 88 Resiprokal Melez Popülasyonunda F $F_{4}$ Kuşağının Allele Özgü Markörlerle Değerlendirilmesi. KSÜ Tarım ve Doğa Derg 23 (6): 1647-1655. DOI: 10.18016/ksutarimdoga.vi.730633.

\section{GİİŞ}

Buğday bitkisi kromozom sayılarına göre diploid $(2 \mathrm{n}=2 \mathrm{x}=14)$, tetraploid $(2 \mathrm{n}=4 \mathrm{x}=28)$ ve hekzaploid $(2 \mathrm{n}=6 \mathrm{x}=42)$ olarak ele alınmaktadır. Hekzaploidler ekmeklik buğday (Triticum aestivum L.) olarak adlandırılmakta ve daha çok un için tercih edilmekte, tetraploid buğday (Triticum durum Desf.) bulgur ve makarna yapımında kullanılmakta, diploidlerin tarımı ise daha çok yerel olarak yapılmaktadır. Son yıllarda az miktarda da olsa özellikle bulgur yapımında diploid buğdaylar da tercih edilmektedir.

Türkiye'de üretim miktarı bakımından tahıllar içerisinde ilk sırada yer alan buğday bitkisinde bölgelere adapte olmuş çeşitlerin seçiminde, kalite ve verim unsurları önemli rol oynamıştır (Güngör ve Dumlupinar, 2019).

Moleküler markörler ıslahta; genetik kaynakların özgünleştirilmesi, ıslah çalışmasında kullanılacak ebeveynlerin belirlenmesi, genotipler arasındaki farklılık ve benzerliklerin belirlenmesi, yeni geliştirilmiş olan genotiplerin korunması ve kalitatif kantitatif genlerin belirlenmesinde kullanılmaktadır (Özcan, 2008). Moleküler markörlerin kaynağını, üretilen bitkilerin DNA'ları oluşturmakta, bitki popülasyonundaki varyasyon ya da çeşitler arasındaki iliş̧i teşhisinde \% 100 doğrulukta sonuç vermektedir (Gülşen ve Mutlu, 2005). Moleküler markör teknolojileri; i) polimeraz zincir reaksiyonu (PZR) temelli (SSR, AFLP ve modifiye formları), ii) hibridizasyon temelli (RFLP, RAPD ve modifiye formları) ve iii) DNA dizileme temelli (EST, SNP vb.) olmak üzere 3 gruba ayrılmaktadır (Khan, 2015). Hibridizasyon temelli moleküler markörler pahalı ve daha uzun süreye ihtiyaç duyduğu için PZR'a dayalı markörler geliştirilmiştir (Özcan, 2008).

Makarnalık buğday ıslah çalışmalarında streslere dayanıklılık yanında verim ve kaliteyi yükseltmek en önemli ıslah hedefleridir. Son yıllarda moleküler markör teknolojilerinin 1slah programlarında kullanımının yaygınlaşması (ön-ıslah) ile birlikte etkin, doğru, çok amaçlı ve erken dönemde seleksiyonun önü açılmıştır. Çünkü, moleküler markör yardımıyla ıslah çalışmalarında istenilen özelliğe sahip genotipler allel spesifik markörlerle belirlenebilmektedir. Böylece, seleksiyonun daha hızlı ve doğru yapılması sağlanmakta ve ıslah süresi de kısaltılmaktadır.

Moleküler markörler genotipleri tanımlanmada, gen (QTL) bölgelerini belirlemede, linkage haritalama çalışmalarında ve genetik çeşitliliğin belirlenmesinde yaygin olarak kullanılmaktadırlar (Leisova ve Ovesna, 2001, Medini ve ark., 2005, Roussel ve ark., 2005, Nersting ve ark., 2006, Leisova ve ark., 2007., Li ve ark. 2000, 2007, Fu ve ark., 2007, He ve Bjornstad, 2012, Montilla-Bascon ve ark., 2013, Dumlupinar ve ark., 2016). Basit dizi tekrarları (SSR), tek nükleotid değişimi (SNP) ve çoğaltılmış parça uzunluğu polimorfizmi (AFLP) bazı moleküler markör teknolojilerindendir. Bunlardan SNP ve SSR markör teknolojileri en yaygın kullanıma sahiplerdir. Tek nükleotid değişimi markörleri yeni nesil dizileme teknolojileri ile birlikte çok fazla üretilebilmeleri ve bu sayede daha kesin sonuçlar verdikleri için günümüzde oldukça yaygın bir kullanıma sahip olmuşlardır. Basit dizi tekrarları markörlerinin kullanımının yaygın olmasının nedeni ise basit kullanımı, fazla miktarda allel üretebilmesi, tekrarlanabilir olması ve yüksek polimorfizm oranlarıdır. SNP ve SSR markörleri, germplazmların değerlendirilmesi ve germplazm koleksiyonlarındaki duplikasyonları önlemede de ideal markörler haline gelmiştir (Devos ve ark., 1995, Plaschke ve ark., 1995, Korzun ve ark., 1997, Leisova ve ark., 2007, Dumlupinar ve ark., 2016).

$\mathrm{Bu}$ çalışmada, kalite ve hastalıklara dayanıklılık yönünden üstün olduğu bilinen B27 yerel makarnalık buğday genotipi ile Türkiye'de önemli bir üretim alanına sahip olan, ancak kalite ve hastalıklara dayanıklılık konusunda iyileştirmeye ihtiyacı olan Ege 88 çeşidi kullanılmıştır. Bu genotiplerin resiproklu olarak melezlenmesinden elde edilen $\mathrm{F}_{4}$ bitkilerinde, DNA markörleri kullanılarak çavdar translokasyonu ve vernalizasyon geninin yanı sira protein oranı, gluten mukavemeti, bin tane ağırlığı, mumsuluk, kara 
pasla ilgili özellikler açısından moleküler olarak karakterizasyon yapılmıştır.

\section{MATERYAL ve METOT}

Çalışmada materyal olarak yerel makarnalık buğday genotipi B27 (Triticum durum Desf.) ve Ege 88 (Triticum durum Desf.) çeşidinin resiproklu olarak melezlenmesi sonucu elde edilen (37) $\mathrm{F}_{4}$ bireyleri ve ebeveynleri ile toplam 39 genotip kullanılmıştır. Genotiplere ait genomik DNA'ların elde edilmesi için tohumlar viyollere ekilmiş ve çimlenme kabininde 25 ${ }^{\circ} \mathrm{C}$ sicaklıkta, 2 yapraklı olana kadar yetiştirilmiştir (Oliver ve ark., 2010). DNA izolasyonu işleminde cetyl trimethyl ammonium bromide (CTAB) yöntemi uygulanmıştır (Oliver ve ark., 2010). Genotiplere ait yaprak örnekleri 2 ml'lik ependorf tüpler içerisinde sıvı azot ile öğütülmüş ve her tüpün içerisine $1 \mathrm{ml} l i k$ izolasyon solüsyonu (1 M Tris- $\mathrm{HCl}(\mathrm{pH}: 8), 0.5 \mathrm{M}$ EDTA (pH:8), $5 \mathrm{M} \mathrm{NaCl}, \% 2$ w/v CTAB, \% 2 polyvinylpyrolidone-40, \% 5 sarcosyl) ilave edilmiştir. Daha sonra tüpler yavaşça altüst edilip 1 saat süreyle $65^{\circ} \mathrm{C}$ ' de su banyosuna alınmıştır. Örnekler su banyosundan çıarıldıktan sonra, $1 \mathrm{ml}$ chloroform: isoamil alkol (24:1) eklenerek 10000 (rpm) devirde 20 dakika santrifüj edilmiştir. Santrifüj işleminden sonra üstte kalan sıvı kısım, altta kalan yaprak parçacıkları ile karıştırılmadan mikro pipet yardımı ile yeni tüplere alınmıştır. Yeni tüplere çekilen sıvı miktarı kadar isopropanol $\left(-20^{\circ} \mathrm{C}\right)$ alkol eklenilerek, 10000 (rpm) devirde, 30 dakika santrifüj edilmiştir. Bu işlem ile DNA'lar tüpün dibine çökmüş ve üstte kalan sıvı kısım DNA'lardan uzaklaştırılmıştır. DNA'ların üzerine $1 \mathrm{ml}$ $\%$ 70'lik etanol eklenerek, 13000 (rpm) devirde 2 dakika santrifüj işlemi uygulanmıştır. Santrifüj işlemi sonrasında sıvı kısım uzaklaştırılmış ve temizlenmiş DNA peletleri kurumaya hazır hale getirilmiştir. DNA peletlerinin üzerine $250 \mu \mathrm{l}$ RNAse solüsyonu $(100 \mathrm{ml}$ $10 \mathrm{mM}$ Tris HCl EDTA solüsyonuna $1 \mathrm{ml}$ RNAse stok solüsyonu) eklenerek DNA izolasyonu tamamlanmıştır. Makarnalık buğday genotiplerinde (37 genotip +2 ebeveyn) bazı özellikler ile ilgili allellerin belirlenmesi için sekiz adet allel spesifik DNA markörü kullanılmıştır. Bu DNA markörlerine ait bilgiler Çizelge 1'de verilmiştir.

Çizelge 1. Moleküler karakterizasyonda kullanılan DNA primerleri

Table 1. DNA primers used in molecular characterization

\begin{tabular}{|c|c|c|c|c|c|c|}
\hline 号莺 & 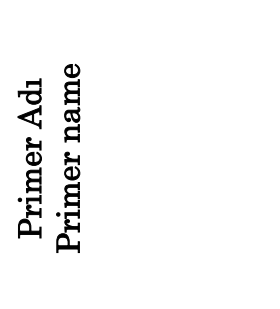 & 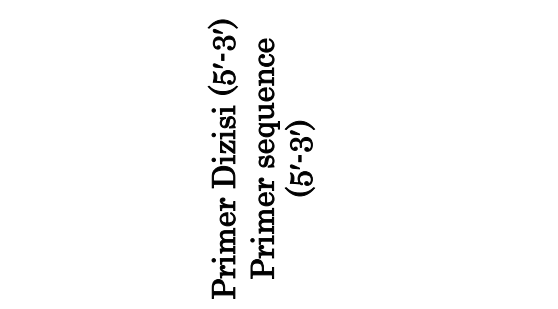 & 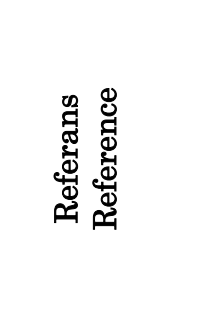 & 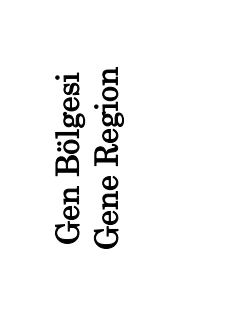 & 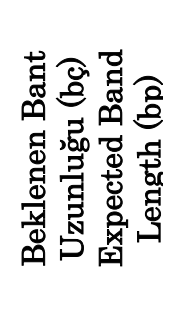 & 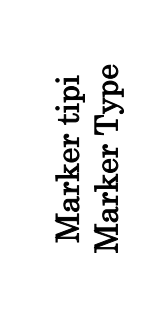 \\
\hline 1 & $\begin{array}{l}\text { Sun1_F } \\
\text { Sun1_R }\end{array}$ & $\begin{array}{l}\text { CGCTCCCTGAAGAGAGAAAGAA } \\
\text { ATAGGCACAACCCCTAAC }\end{array}$ & $\begin{array}{l}\text { Sharoflou ve } \\
\text { Sharp, } 1999\end{array}$ & $\begin{array}{l}\text { Mumusuluk } \\
\text { Waxy } \\
W_{x}-A 1\end{array}$ & $\begin{array}{l}\text { Xsun- } \\
7 \mathrm{~A}, 219, \\
233,260, \\
271,275, \\
285 \quad \text { ve } \\
289\end{array}$ & Eş baskın \\
\hline 2 & $\begin{array}{l}\text { Sun209_F } \\
\text { Sun209_R }\end{array}$ & $\begin{array}{l}\text { AGCTATGAGCTTCGCTATTG } \\
\text { GTGATTGGTTCGGATTACTTA }\end{array}$ & $\begin{array}{l}\text { Bansal ve } \\
\text { ark., } 2015\end{array}$ & $\begin{array}{l}\text { Kara pas } \\
\text { Sr49 }\end{array}$ & 148 & Eş Baskın \\
\hline 3 & $\begin{array}{l}\text { Sun479_F } \\
\text { Sun479_R }\end{array}$ & $\begin{array}{l}\text { CAAATGAAATGTGATCCTGTT } \\
\text { TCATCTAACCAGCAATGGTAT }\end{array}$ & $\begin{array}{l}\text { Bansal ve } \\
\text { ark., } 2015\end{array}$ & $\begin{array}{l}\text { Kara pas } \\
\text { Sr49 }\end{array}$ & 200 & Eş Baskın \\
\hline 4 & $\mathrm{Bx}^{7 \mathrm{TE}}-\mathrm{F}^{\mathrm{B} x^{7 \mathrm{OE}}}-\mathrm{R}$ & $\begin{array}{l}\text { CCTCAGCATGCAAACATGCAGC } \\
\text { CTGAAACCTTTGGCCAGTCATGTC }\end{array}$ & $\begin{array}{l}\text { Butow ve } \\
\text { ark., } 2003\end{array}$ & $\begin{array}{l}\text { Gluten } \\
\text { Mukavemeti } \\
\text { Glu-B1 }\end{array}$ & 563 & Eş Baskın \\
\hline 5 & $\begin{array}{l}\text { UHW89_F } \\
\text { UHW89_R }\end{array}$ & $\begin{array}{l}\text { TCTCCAAGAGGGGAGAGACA } \\
\text { TTCCTCTACCCATGAATCTAGCA }\end{array}$ & $\begin{array}{l}\text { Distelfeld ve } \\
\text { ark., } 2006\end{array}$ & $\begin{array}{l}\text { Yüksek } \\
\text { Protein } \\
G p c-B 1\end{array}$ & 122 & Eş Baskın \\
\hline 6 & $\begin{array}{l}\text { RİS_F } \\
\text { RİS_R }\end{array}$ & $\begin{array}{l}\text { TAATTTCTGCTTGCTCCATGC } \\
\text { ACTGGGGTGCACTGGATTAG }\end{array}$ & $\begin{array}{l}\text { Koebner, } \\
1995\end{array}$ & $\begin{array}{l}\text { Çavdar } \\
\text { Translokasyo } \\
\text { nu 1AL.1RS }\end{array}$ & 110 & Baskın \\
\hline 7 & $\begin{array}{l}\text { XGWM68_F } \\
\text { XGWM68_R }\end{array}$ & $\begin{array}{l}\text { AGGCCAGAATCTGGGAATG } \\
\text { CTCCCTAGATGGGAGAAGGG }\end{array}$ & $\begin{array}{l}\text { Roder ve ark., } \\
\text { 1998) }\end{array}$ & $\begin{array}{ll}\text { Bin } & \text { Tane } \\
\text { Ağırlığ } & \end{array}$ & 166 & Eş Baskın \\
\hline 8 & VRN1-F VRN1-R & $\begin{array}{l}\text { GAAAGGAAAAATTCTGCTCG } \\
\text { GCACGAAATCGAAATCGAAG }\end{array}$ & $\begin{array}{l}\text { Yan ve ark., } \\
2004\end{array}$ & $\begin{array}{l}\text { Vernalizasyon } \\
\text { Vrn }-A 1\end{array}$ & 464 & Baskın \\
\hline
\end{tabular}

Polimeraz zincir reaksiyonları (PZR) $0.02 \quad \mathrm{ml}$ hacmindeki 96'lık PZR platelerine; $1 \mu \mathrm{dNTP}$ karışımı $(10 \mathrm{mM}$ karışım $(\mathrm{A}+\mathrm{T}+\mathrm{G}+\mathrm{C})), 3 \mu \mathrm{l}$ 10x buffer, $1.2 \mu \mathrm{l}$
MgCI2, SSR primer çifti ( $1 \mu \mathrm{l} \mathrm{F}$ ve $1 \mu \mathrm{l} \mathrm{R}$ ), $3 \mu \mathrm{l}$ (50 ng) genomik DNA, $9.5 \mu \mathrm{l} \mathrm{ddH}_{2} \mathrm{O}$, ve $0.3 \mu \mathrm{l}$ Taq DNA

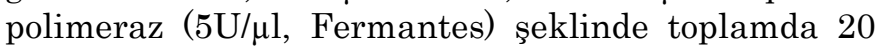


l'lik PZR solüsyonu hazırlanarak "eppendorf" marka thermal cycler cihazında; $95{ }^{\circ} \mathrm{C}$ 'de 5 dakika çalıştırılmıştır. Daha sonra $95{ }^{\circ} \mathrm{C}$ 'de (DNA iplikçilerinin ayrışması) 1 dakika, $55{ }^{\circ} \mathrm{C}$ 'de (primerlerin yapışması, tavlama) 1 dakika ve $72{ }^{\circ} \mathrm{C}$ 'de (DNA eşleşmesi) 1 dakika olmak üzere cihaz çalıştırılmıştır. Aynı zamanda $95{ }^{\circ} \mathrm{C}$ ile $72{ }^{\circ} \mathrm{C}$ arasında 35 döngü yapması sağlanarak, son aşamada $72^{\circ} \mathrm{C}$ 'de 5 dakika çalıştırılıp reaksiyon tamamlanmıştır. Elde edilen PZR ürünleri $-20 \quad{ }^{\circ} \mathrm{C}$ tutulmuştur. PZR işleminden sonra fragment analizleri için elde edilen ürünler, Qiagen firmasına ait "QIAxcel Advanced System" fragment analiz cihazında yürütülmüş ve genotiplere ait DNA bantları elde edilmiştir. Çalışmada, okuma aralığını belirleyebilmek için genotiplerin fragment analizi sonuçlarına bakılıp, elde edilen sonuçlara göre okuma aralığı 15 ile 5000 baz çifti (bç) arası tercih edilmiştir. Skorlama esnasında hassasiyet \pm 4 bç olarak kabul edilmiş ve alleller buna göre değerlendirilmiştir. NTSYSpc 2.21q (Rohlf, 2005) programında Dice indeks (Dice, 1945) kullanılarak genotiplerin birbirleriyle genetik olarak benzerlikleri hesaplanmıştır. Genotiplere ait DNA bantları "0" veya "1" olarak kodlanmış ve ikili (binary) veri matriksi oluşturulmuştur. Oluşturulan matriks yardımıyla
UPGMA (Unweighted Pair Group Method Arithmetic Average) kullanılarak, genotiplerin benzerliklerini gösteren dendrogram elde edilmiştir. Moleküler analizlerde kullanılan her bir DNA markörü için polimorfizm bilgi içerikleri (PIC), Weir (1996)'e göre aşağıda belirtilen formülle hesaplanmıştır.

$\mathrm{PIC}=1-\sum \mathrm{Pi}^{2}$

$\mathrm{Pi}$; araştırmada çalışılan 39 adet makarnalık buğday genotipinde (37 $\mathrm{F}_{4}$ bireyi + iki ebeveyn) i'inci allelin frekansidır.

\section{BULGULAR ve TARTIŞMA}

Araştırmada kullanılan 39 farklı makarnalık buğday genotipi arasındaki benzerlikler ve farklılıklar, sekiz adet allel spesifik DNA markörü ile taranmış ve 56 adet polimorfik bant tespit edilmiştir (Çizelge 2). B27, Ege 88 ve resiprokal $\mathrm{F}_{4}$ döl kuşaklarının fonksiyonel markörler ile karakterizasyonu sonucu elde edilen allelik varyasyonlarma ait bilgiler Çizelge 3'te verilmiştir. Araştırmada kullanılan markörlerden SUN1'e ait fragment analizi görüntüsü Şekil 1'de, 56 bant kullanılarak oluşturulan dendrogram Şekil 3’te gösterilmiştir.

Çizelge 2. DNA markörlerinin PIC değerleri ve toplam allel sayıları

Table 2. PIC values and total allele numbers of DNA markers

\begin{tabular}{llll}
\hline No/Number & Primer Adı/Primer Name & Allel Sayıs//Allele Number & PIC Değeri/PIC Value \\
\hline 1 & SUN1 & 7 & 0.99 \\
2 & SUN209 & 2 & 0.92 \\
3 & SUN479 & 15 & 0.99 \\
4 & Bx $^{70 E}$ & 1 & 0.99 \\
5 & UHW89 & 5 & 0.39 \\
6 & RIS & 10 & 0.99 \\
7 & VRN1 & 13 & 0.99 \\
8 & XGWM68 & 3 & 0.74 \\
\hline Ortalama & & 7 & 0.87 \\
\hline
\end{tabular}

Araştırmada kullanılan DNA markörlerinin ortalama allel sayısı 7 olurken, en çok allel üreten markör 15 bant ile Sun 479, en az allel üreten markör bir adet bant ile Bx7OE olmuştur. Çalışma sonucuna göre ortalama polimorfizm bilgi içeriği (PIC) değeri 0.87 olurken, en yüksek PIC değeri 0.99 (SUN1, SUN479, Bx70E, RIS ve VRN1) ve en düşük PIC değeri ise 0.39 (UHW89) olarak bulunmuştur. Doğrar ve ark. (2008), kışlık makarnalık buğdaylarda SSR markörlerinde \% 60.9 ile 87.2 arasında değişen bir polimorfizm bilgi içeriği değeri bildirirken, Akar (2002), makarnalık buğdaylarda, RAPD markörlerinde \% 74 ile 99 arasında bir PIC değeri belirtmiştir. Bilgin ve Korkut (2005) ise, ekmeklik buğday çeşit ve hatlarında, RAPD markörlerinde \% 94 PIC değeri bulmuşlardır. Özbek (2006), yabani tetraploid buğdaylarda AFLP primerleri ile yaptığı çalışmada, Türkiye orijinliler için $\%$ 40.5, İsrail orijinliler için ise \% 48.6 PIC değeri saptamıştır. Motawei ve ark. (2007), RAPD markörlerinde \% 71, Abdul ve Tahır (2008) SSR markörleri ile yaptığı çalışmada ekmeklik buğdaylar için \% 28.6, makarnalık buğdaylar için ise \% 33.3 ile 81.8 arasında PIC değeri belirlemişlerdir. Kekilli (2019) ticari makarnalık buğdaylar ile yaptığ çalışmada, bazı kalite ve hastalıkla ilgili fonksiyonel markörlerde \% 85 PIC değeri, Güngör (2019) ise çalışmasında \% 72.5 PIC değeri belirlemiştir.

Sharoflou ve Sharp (1999) tarafından geliştirilen ve mumsuluk özelliğine ait gen $\left(W_{x}-A 1\right)$ ile ilişkilendirilen SUN1 primeri kullanılarak makarnalık buğday genotipleri taranmıştır. Tarama sonuçlarına göre B27, Ege 88, B27 × Ege 88_2 ve B27 $\times$ Ege 88_4 genotiplerinde mumsuluk $\left(W_{X^{-}} A 1\right)$ özelliğine ait genler (234 bç) belirlenmiştir. Mumsuluk $\left(W_{x}-A 1\right) \quad$ özelliğini belirlemede SUN1 primerini kullanarak, Maryami ve ark. (2014) 230 ve 265 bç, Shariflou ve Sharp (1999) 219, 233, 260, 271, 275, 285 ve 289 bç uzunluklarında alleller tespit etmişlerdir. 


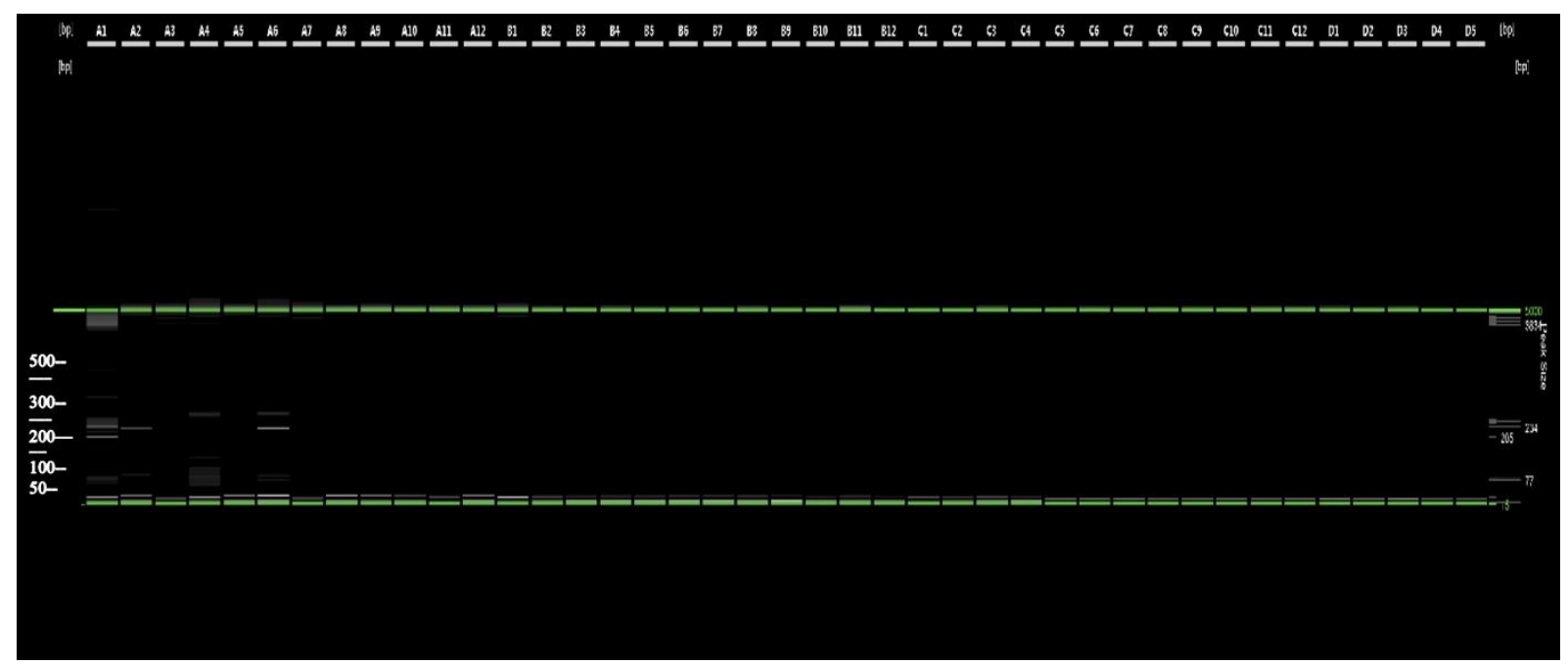

Şekil 1. SUN1 primerine ait fragment analizi görüntüsü (A1:B27, A2:Ege 88, A3: B27 × Ege 88_1, A4: B27 × Ege 88_2, A5: B27 $\times$ Ege 88_3, A6: B27 × Ege 88_4, A7: B27 × Ege 88_5, A8: B27 × Ege 88_6, A9: B27 × Ege 88_7, A10: B27 × Ege 88_8, A11: B27 × Ege 88_9, A12: B27 × Ege 88_10, B1: B27 × Ege 88_11, B2: B27 × Ege 88_12, B3: B27 × Ege 88_13, B4:B27 $\times$ Ege 88_14,B5:B27 × Ege 88_15, B6: B27 × Ege 88_16, B7: B27 × Ege 88_17, B8: B27 × Ege 88_18, B9: B27 × Ege 88_19, B10: Ege $88 \times$ B27_1, B11: Ege $88 \times$ B27_2, B12: Ege $88 \times$ B27_3, C1: Ege $88 \times$ B27_4, C2: Ege 88 × B27_5, C3: Ege $88 \times$ B27_6, C4: Ege $88 \times$ B27_7, C5: Ege $88 \times$ B27_8, C6: Ege $88 \times$ B27_9, C7: Ege $88 \times$ B27_10, C8: Ege 88 $\times$ B27_11, C9: Ege $88 \times$ B27_12, C10: Ege $88 \times$ B27_13, C11: Ege $88 \times$ B27_14, C12: Ege $88 \times$ B27_15, D1: Ege 88 $\times$ B27_16, D2: Ege $88 \times$ B27_17, D3: Ege $88 \times$ B27_18)

Figure 1. Fragment analysis image of SUN1 primer (A1:B27, A2:Ege 88, A3:B27 x Ege 88_1, A4: B27 x Ege 88_2, A5:B27 x

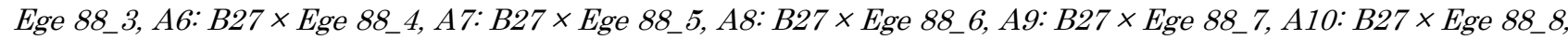
A11: B27 X Ege 88_9, A12: B27 × Ege 88_10, B1:B27 × Ege 88_11, B2:B27 × Ege 88_12, B3:B27 X Ege 88_13, B4:B27 $\times$ Ege 88_14,B5:B27 $\times$ Ege 88_15, B6: B27 $\times$ Ege 88_16, B7: B27 $\times$ Ege 88_17, B8: B27 $\times$ Ege 88_18, B9: B27 $\times$ Ege 88_19, B10: Ege $88 \times$ B27_1, B11: Ege 88 $\times$ B27_2, B12: Ege $88 \times$ B27_3, C1: Ege 88 $\times$ B27_4, C2: Ege 88 $\times$ B27_5, C3: Ege $88 \times$ B27_6, C4: Ege $88 \times$ B27_7, C5: Ege $88 \times$ B27_8, C6: Ege 88 $\times$ B27_9, C7: Ege 88 $\times$ B27_10, C8: Ege 88 $\times$ B27_11, C9: Ege $88 \times$ B27_12, C10: Ege $88 \times$ B27_13, C11: Ege $88 \times$ B27_14, C12: Ege 88 $\times$ B27_15, D1: Ege 88 $\times$ B27_16, D2: Ege $88 \times$ B27_17, D3: Ege $88 \times$ B27_18)

Araştırmada kullanılan kara pas geni (Sr49) ile ilişkili SUN209 primerinden B27 × Ege 88_2, B27 × Ege 88-4, B27 × Ege 88_5, B27 $\times$ Ege 88_6, B27 $\times$ Ege 88_9, B27 $\times$ Ege $88 \_14$, B2 $7 \times$ Ege $88 \_18$, Ege $88 \times$ B27_2, Ege $88 \times$ B27_9 ve Ege $88 \times$ B27_14 beklenen uzunlukta (148 bç) bant elde edilmiştir. Bansal ve ark. (2015) yaptıkları araştırmada, SUN209 primerinin çoğalttığı 148 bç DNA bandının, kara pas hastalığına dayanıklılık geniyle (Sr49) bağlantılı olduğunu belirlemişlerdir. Kara pasa dayanıklılık geni $(S r 49)$ ile ilişkili markörlerden bir tanesi de SUN479 primeridir. Makarnalık buğday $\mathrm{F}_{4}$ döl kuşaklarından B27 $\times$ Ege 88_16, B27 × Ege 88_17, B27 $\times$ Ege 88_18, B27 $\times$ Ege 88_19, Ege $88 \times$ B27_1 ve Ege $88 \times$ B27_3 kara pas hastalığına dayanıklılık geni (204 bç) belirlenmiştir. Bansal ve ark. (2015), SUN479 primerini kullanarak kara pasa dayanıklılık genini (Sr49) belirlemek için yaptıkları araştırmada 200 bç uzunluğunda DNA bandını, kara pas dayanıklılık geni $(S r 49)$ ile ilişkili olduğunu tespit etmişlerdir.

Gluten mukavemetini kontrol eden genlerden birisi olan Glu-B1 ile ilişkili olduğu bilinen $\mathrm{Bx} 7^{\mathrm{OE}}$ primeri, $\mathrm{F}_{4}$ döl kuşaklarından B27 × Ege 88_14 ve Ege $88 \times$ B27_4'te istenilen uzunlukta (563 bç) bant üretmiştir. Butow ve ark. (2003), Bx7 ${ }^{\mathrm{OE}}$ primerini kullanarak yaptıkları çalışmada, bu primerin 750 bç kısmına denk gelen eş-baskın bir işaretleyici ve Glu-B1 (520 bç)'yi içermeyen hatların 43 bç bir ilave ile 563 bç uzunluğunda alleller saptadıklarını belirtmişlerdir. UHW89 primeri yüksek protein oranı $G p c-B 1$ genini belirlemede kullanılan bir belirteçtir. Çalışmamızda kullandığımız B27, Ege 88, B27 × Ege 88_1, B27 × Ege 88_2, B27 $\times$ Ege 88_3, B27 $\times$ Ege 88_4, B27 $\times$ Ege 88_5, B27 $\times$ Ege 88_6, B27 $\times$ Ege 88_7, B27 $\times$ Ege 88_8, B27 $\times$ Ege 88_9, B27 $\times$ Ege 88_10, B27 $\times$ Ege 88_11, B27 $\times$ Ege 88_12, B27 $\times$ Ege 88_13, B27 $\times$ Ege 88_14, B27 $\times$ Ege 88_15, B27 $\times$ Ege 88_17, B27 $\times$ Ege 88_18, B27 $\times$ Ege 88_19, Ege $88 \times$ B27_1, Ege $88 \times$ B27_2, Ege $88 \times$ B27_4, Ege $88 \times$ B27_5, Ege $88 \times$ B27_6, Ege $88 \times$ B27_7, Ege $88 \times$ B27_8, Ege $88 \times$ B27_9, Ege $88 \times$ B2712, Ege $88 \times$ B27_13, Ege $88 \times$ B27_14, Ege $88 \times$ B27_15, Ege $88 \times$ B27_17 ve Ege $88 \times$ B27_18 genotiplerinde istenilen uzunlukta (122 bç) yüksek protein oranı ile ilşkili allel $(G p c-B 1)$ tespit edilmiştir. Distelfeld ve ark. (2006), UHW89 primerini kullanarak, 122 ve 126 bç uzunluğunda alleller elde etmiş, 4 baz çiftlik polimorfizmin ACTT duplikasyonu sonucunda meydana geldiğini belirtmişlerdir.

Çavdar translokasyonuna ait gen (1AL.1RS) belirlemede kullanılan markörlerden RIS primeri, $\mathrm{F}_{4}$ döl kuşaklarından B27 × Ege 88_13 ve B27 × Ege 88_19'da beklenen uzunlukta (110 bç) DNA bantları 
vermiş ve çavdar translokasyonlarına ait genin (1AL.1RS) bulunduğu saptanmıştır. Koebner (1995) yürüttüğü çalışmada, RIS primerinin 110 baz çiftinde bant verdiğini, Yediay ve ark. (2010) RIS primerini kullanarak yaptıkları araştırmada, 117 baz çifti uzunluğunda bant elde ettiklerini belirtmişlerdir.

VRN1 vernalizasyon genlerinden bir tanesi olan VrnA1'i belirlemede kullanılan bir primerdir. Araştırmada kullanilan genotiplerde bu primere ait beklenen uzunlukta (464 bç) bant tespit edilememiştir. Ayrıca, bin tane ağırlığı ile ilişkili Xgwm68 primeri de araştırmada kullanılan genotiplerde beklenen uzunlukta (166 bç) bant üretmemiştir (Çizelge 3).

Markör verileri kullanılarak oluşturulan dendrogram iki ana gruba ayrılmıştır. Birinci grupta sadece Ege 88 $\times$ B27_3 genotipi yer alırken diğer genotiplerden \% 97 farklı bulunmuş, ikinci grupta ise hem ebeveynler hem de popülasyona ait diğer melezler tespit edilmiştir. Ege $88 \times$ B27_7 ile Ege $88 \times$ B27_8 ve B27 × Ege 88_5 ile B27 × Ege 88_6 genotiplerinde genetik benzerlik \% 100 olarak tespit edilmiştir.

Çizelge 3. B27, Ege 88 ve resiproklu $\mathrm{F}_{4}$ döl kuşaklarına ait allelik varyasyonlar

Table 3. Allelic variation of B27, Ege 88 and reciprocal $F_{4}$ population

\begin{tabular}{|c|c|c|c|c|c|c|c|c|}
\hline $\begin{array}{l}\text { Markör /Marker } \\
\text { Genotip/Genotype }\end{array}$ & SUN1 & SUN209 & SUN479 & $\mathrm{Bx} 7^{\mathrm{OE}}$ & UHW89 & RIS & VRN1 & XGWM68 \\
\hline B27 & + & - & - & - & + & - & - & - \\
\hline Ege 88 & + & - & - & - & + & - & - & - \\
\hline B27 $\times$ Ege $88-1$ & - & - & - & - & + & - & - & - \\
\hline B27 $\times$ Ege 88-2 & + & + & - & - & + & - & - & - \\
\hline B27 $\times$ Ege $88^{-3}$ & - & - & - & - & + & - & - & - \\
\hline B27 $\times$ Ege 88-4 & + & + & - & - & + & - & - & - \\
\hline B27 $\times$ Ege 88-5 & - & + & - & - & + & - & - & - \\
\hline B27 $\times$ Ege $88^{-6}$ & - & + & - & - & + & - & - & - \\
\hline B27 $\times$ Ege $88^{-7}$ & - & - & - & - & + & - & - & - \\
\hline B27 $\times$ Ege $88-8$ & - & - & - & - & + & - & - & - \\
\hline B27 $\times$ Ege $88-9$ & - & + & - & - & + & - & - & - \\
\hline B27 $\times$ Ege $88-10$ & - & - & - & - & + & - & - & - \\
\hline B27 $\times$ Ege $88-11$ & - & - & - & - & + & - & - & - \\
\hline B27 $\times$ Ege $88-12$ & - & - & - & - & + & - & - & - \\
\hline B27 $\times$ Ege $88-13$ & - & - & - & - & + & + & - & - \\
\hline B27 $\times$ Ege $88-14$ & - & + & - & + & + & - & - & - \\
\hline B27 $\times$ Ege $88-15$ & - & - & - & - & + & - & - & - \\
\hline B27 $\times$ Ege $88-16$ & - & - & + & - & - & - & - & - \\
\hline B27 $\times$ Ege $88-17$ & - & - & + & - & + & - & - & - \\
\hline B27 $\times$ Ege $88-18$ & - & + & + & - & + & - & - & - \\
\hline B27 $\times$ Ege $88-19$ & - & - & + & - & + & + & - & - \\
\hline Ege $88 \times \mathrm{B} 27-1$ & - & - & + & - & + & - & - & - \\
\hline Ege $88 \times$ B27-2 & - & + & - & - & + & - & - & - \\
\hline Ege $88 \times$ B27-3 & - & - & + & - & - & - & - & - \\
\hline Ege $88 \times$ B27-4 & - & - & - & + & + & - & - & - \\
\hline Ege $88 \times$ B27-5 & - & - & - & - & + & - & - & - \\
\hline Ege $88 \times$ B27-6 & - & - & - & - & + & - & - & - \\
\hline Ege $88 \times$ B27-7 & - & - & - & - & + & - & - & - \\
\hline Ege $88 \times$ B27-8 & - & - & - & - & + & - & - & - \\
\hline Ege $88 \times$ B27-9 & - & + & - & - & + & - & - & - \\
\hline Ege $88 \times B 27-10$ & - & - & - & - & - & - & - & - \\
\hline Ege $88 \times \mathrm{B} 27-11$ & - & - & - & - & - & - & - & - \\
\hline Ege $88 \times$ B27-12 & - & - & - & - & + & - & - & - \\
\hline Ege $88 \times \mathrm{B} 27-13$ & - & - & - & - & + & - & - & - \\
\hline Ege $88 \times B 27-14$ & - & + & - & - & + & - & - & - \\
\hline Ege $88 \times$ B27-15 & - & - & - & - & + & - & - & - \\
\hline Ege $88 \times$ B27-16 & - & - & - & - & + & - & - & - \\
\hline Ege $88 \times$ B27-17 & - & - & - & - & + & - & - & - \\
\hline Ege $88 \times$ B27-18 & - & - & - & - & + & - & - & - \\
\hline
\end{tabular}




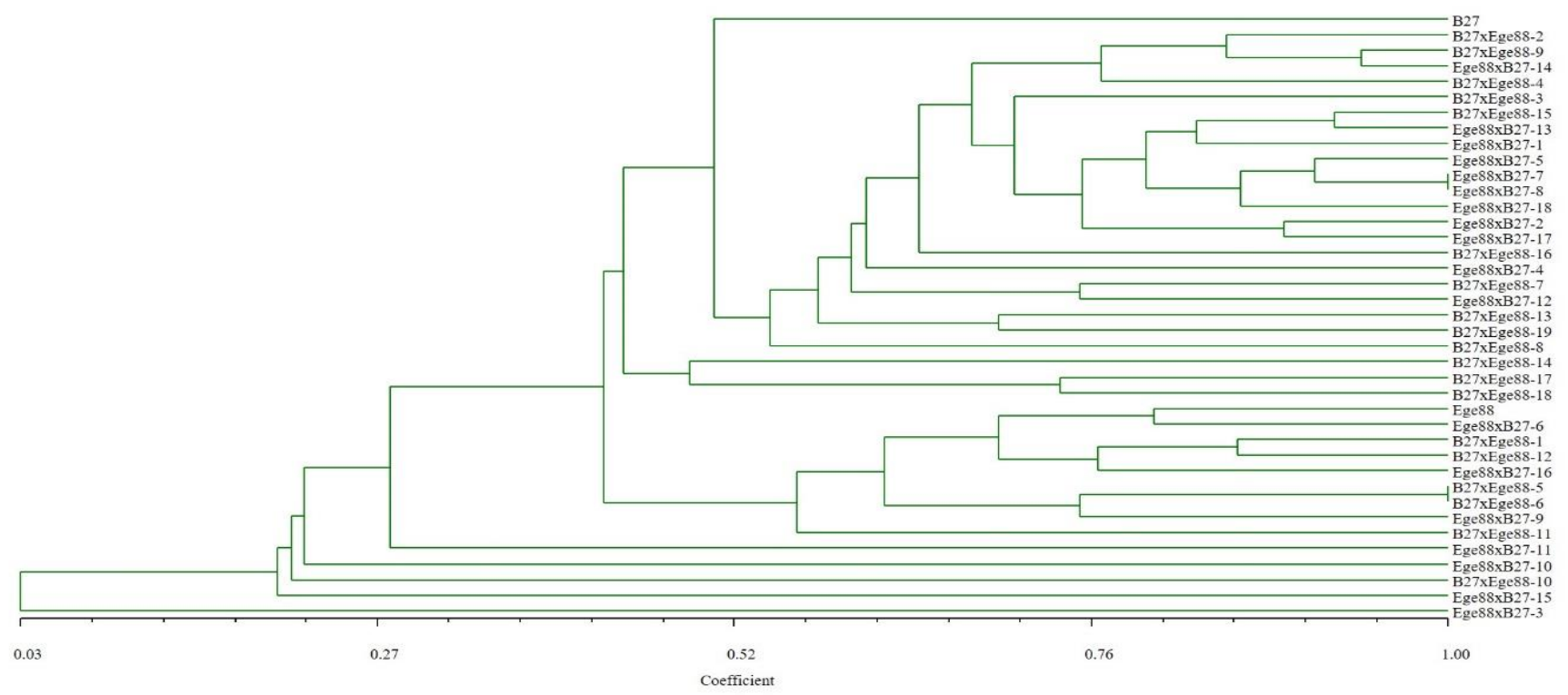

Şekil 2. DNA markörleri ile taranarak elde edilen veriler sonucunda oluşturulan filogenetik ağaç Figure 2. A dendrogram was created as a result of data obtained by screening with DNA markers

Medini ve ark. (2005), Tunus orijinli makarnalık buğdaylarını yabanilerinden ayırmak amacıyla yürüttükleri çalışmada, AFLP ve SSR primerleri kullanılmışlar ve SSR primerinde genetik çeşitliliğin 0.036-0.727, AFLP primerinde genetik çeşitliliğin 0.313-0.81 arasında farklılık gösterdiğini tespit etmişlerdir. Çifci ve Yağdı (2011), 14 ticari makarnalık buğday çeşidini RAPD markörleri kullanarak karakterize etmişler ve genetik çeşitlilik oranının 0.434 ile 0.874 arasında olduğunu tespit etmişlerdir. Kiraz ve ark. (2019), ekmeklik buğday mutantlarında 0.22 ile 0.76 arasında bir genetik çeşitlilik bildirirken, Güngör (2019) ticari ve yerel makarnalık buğdaylarda 0.49 ile 0.86 arasında bir genetik çeşitlilik saptamıştır.

\section{SONUÇ ve ÖNERILLER}

Bu çalışmada 39 adet makarnalık buğday genotipi, sekiz adet allel spesifik DNA markörü ile değerlendirilerek, bu genotiplerin bazı özellikler ile ilgili allelleri tespit edilmiştir.

Araştırmada, 56 adet polimorfik bant elde edilmiş ve ortalama bant sayısı 7 olarak tespit edilmiştir. En çok bant üreten markör 15 bant ile Sun 479, en az bant üreten markör 1 adet bant ile $\mathrm{Bx} 7^{\mathrm{OE}}$ olmuştur. Ortalama polimorfizm bilgi içeriği (PIC) değeri ortalama 0.875 olarak bulunmuştur. En yüksek PIC değeri 0.99 ile SUN1, SUN479, Bx7OE, RIS ve VRN1 markörlerinden, en düşük PIC değeri ise 0.39 ile UHW89 marköründen elde edilmiştir.

Elde edilen markör verileri ile bir dendrogram oluşturulmuştur. Buna göre, Ege 88 × B27_3 döl kuşağının diğerlerine genetik olarak \% 3 benzer olduğu, Ege $88 \times$ B27_7 ile Ege $88 \times$ B27_8 ve B27 $\times$ Ege 88_5 ile B27 $\times$ Ege 88_6 genotiplerinin ise \% 100 benzer olduğu sonucuna varılmıştır.
Araştırmada kullanılan B27, Ege 88, B27 × Ege 88_2, B27 $\times$ Ege 88_4 genotiplerinde mumsuluk $\left(W_{x}-A 1\right)$ geni, B27 $\times$ Ege 88_2, B27 $\times$ Ege 88-4, B27 $\times$ Ege 88_5, B27 $\times$ Ege 88_6, B27 $\times$ Ege 88_9, B27 $\times$ Ege 88_14, B27 $\times$ Ege 88_16, B27 $\times$ Ege 88_17, B27 $\times$ Ege 88_18, B27 $\times$ Ege 88_19, Ege $88 \times$ B27_1, Ege $88 \times$ B27_2, Ege 88 $\times$ B27_3, Ege $88 \times$ B27_9 ve Ege $88 \times$ B27_14 genotiplerinde kara pasa dayanıklılık geni (Sr49) tespit edilmiştir. B27, Ege 88, B27 $\times$ Ege 88_1, B27 $\times$ Ege 88_2, B27 $\times$ Ege 88_3, B27 $\times$ Ege 88_4, B27 $\times$ Ege 88_5, B27 $\times$ Ege 88_6, B27 $\times$ Ege 88_7, B27 $\times$ Ege 88_8, B27 $\times$ Ege 88_9, B27 $\times$ Ege 88_10, B27 $\times$ Ege 88_11, B27 $\times$ Ege 88_12, B27 $\times$ Ege 88_13, B27 $\times$ Ege 88_14, B27 $\times$ Ege 88_15, B27 $\times$ Ege 88_17, B27 $\times$ Ege 88_18, B27 $\times$ Ege 88_19, Ege $88 \times$ B27_1, Ege $88 \times$ B27_2, Ege $88 \times$ B27_4, Ege $88 \times$ B27_5, Ege $88 \times$ B27_6, Ege $88 \times$ B27_7, Ege $88 \times$ B27_8, Ege $88 \times$ B27_9, Ege $88 \times$ B27_12, Ege $88 \times$ B27_13, Ege $88 \times$ B27_14, Ege $88 \times$ B27_15, Ege $88 \times$ B27_16, Ege $88 \times$ B27_17 ve Ege 88 $\times$ B27_18 genotiplerinde yüksek protein geni $(G p c-B 1)$ belirlenmiştir. Ayrıca, B27 × Ege 88_14 ve Ege $88 \times$ B27_4 genotiplerinde gluten mukavemeti geni (Glu$B 1)$, ve B27 × Ege 88_13 ve B27 × Ege 88_19 genotiplerinde çavdar translokasyonlarına ait gen tespit edilmiştir. Xgwm68 ve VRN1 primerlerinden beklenen uzunlukta bant elde edilememiştir.

\section{Çıkar İlişkisi}

Yazarlar bu çalışmada hiçbir çıkar ilişkisi olmadığını beyan etmektedirler.

\section{Çıkar Çatışması Beyanı}

Makale yazarları aralarında herhangi bir çıkar çatışması olmadığını beyan ederler. 


\section{Araştırmacıların Katkı Oranı Beyan Özeti}

Yazarlar makaleye eşit oranda katkı sağlamış olduklarını beyan ederler.

\section{KAYNAKLAR}

Abdul N, Tahır R 2008. Germination Characteristics and Molecular Characterizations of Some Wheat Varieties in Sulaimanyah by SSR Marker. Turkish Journal of Biology 34: 109-117.

Akar T 2002. Türkiye'de Yetiştirilen Yerel Makarnalık Buğday Çeşitlerinde Genetik Farklılığın Polimorfik DNA Analizi ile Belirlenmesi. Ankara Üniversitesi Fen Bilimleri Enstitüsü Tarla Bitkileri Anabilim Dall, Yayınlanmamıs Doktora Tezi, 98sy

Bansal UK, Muhammad S, Forrest KL, Hayden MJ, Bariana HS 2015. Mapping of A New Stem Rust Resistance Gene Sr49 in Chromosome 5B of Wheat. Theoretical and Applied Genetics 128: 2113-2119.

Bilgin O, Korkut Z 2005. Bazı Ekmeklik Bugday (Triticum Aestivum) Çeşit ve Hatlarının Genetik Uzaklıklarının Belirlenmesi. Tekirdağ Ziraat Fakültesi Dergisi 2 (3): 245-252.

Butow BJ, Ma W, Gale KR, Cornish GB, Rampling L, Larroqueand O, Bekes F 2003. Molecular Discrimination of $\mathrm{Bx} 7^{\mathrm{OE}}$ Alleles Demonstrates That A Highly Expressedhigh-Molecular-Weight Glutenin Allele Has A Major Impact on Wheat Flourdough Strength. Theoretical And Applied Genetics 107(8): 1524-1532.

Çifci AE, Yağdı K 2011. Türkiye'de Yetiştirilen Bazı Makarnalık Buğday Çeşitlerinde Genetik Farklılıkların Belirlenmesi, Uludağ Üniversitesi Ziraat Fakültesi Dergisi 25(2): 7-18.

Devos KM, Bryan GJ, Collins AJ, Stephenson P, Gale MD 1995. Application of Two Microsatellite Sequences in Wheat Storage Proteins as Molecular Markers. Theoretical and Applied Genetics 90: 241252.

Dice LR 1945. Measures of the Amount of Ecologic Association between Species. Ecology 26, S. 297302.

Distelfeld A, Uauy C, Fahima T, Dubcovsky J 2006. Physical Map of the Wheat Highgrain Protein Content Gene Gpc-B1 and Development of A HighThroughput Molecular Marker. New Phytologist 169: 753-763.

Dograr N, Akın-Yalın A, Akkaya MS 2008. Discriminating Durum Wheat Cultivars Using Highly Polymorphic Simple Sequence Repeat DNA Markers. Plant Breeding 119: 360-362.

Dumlupinar Z, Jellen EN, Bonman JM, Jackson EW 2016. Genetic Diversity and Crown Rust Resistance of Oat Landraces from Various Locations throughout Turkey. DOI: 10.3906/Tar-1509-43, Turk J Agric For 40: 262-268.

Fu YB, Peterson GW, Chong J, Fetch T, Wang ML 2007. Microsatellite Variation in Avena sterilis Oat
Germplasm. Theoretical and Applied Genetics 114: 10229-11038.

Gülşen O, Mutlu N 2005. Bitki Biliminde Kullanılan Genetik Markırlar ve Kullanım Alanları. Alatarım 4 (2): 27-37.

Güngör H 2019. Allelic Variations and Agronomic Comparisons of Durum Wheat Cultivars under East-Mediterranean Conditions International Journal of Agriculture and Biology 21(4):891-898 DOI: $10.17957 / \mathrm{IJAB} / 15.0972$.

Güngör H, Dumlupınar Z 2019. Bolu Koşullarında Bazı Ekmeklik Buğday (Triticum aestivum L.) Çeşitlerinin Verim, Verim Unsurları ve Kalite Yönünden Değerlendirilmesi. Türk Tarım ve Doğa Bilimleri Dergisi 6 (1): 44-51.

He X, Bjornstad A 2012. Diversity of North European Oat Analyzed by SSR, AFLP and Dart Markers. Theoretical and Applied Genetics 125: 57-70.

Kekilli Ö 2019. Bazı Makarnalık Buğday Çeşitlerinin Allel Spesifik DNA Markörlerle Karakterizasyonu, Kahramanmaraş Sütçü İmam Üniversitesi Fen Bilimleri Enstitüsü Tarımsal Biyoteknoloji Anabilim Dal, Yüksek Lisans Tezi. $30 \mathrm{~s}$.

Khan F 2015. Molecular Markers: An Excellent Tool for Genetic Analysis. J Mol Biomark Diagn 6: 233. doi: 10.4172/2155-9929.1000233.

Kiraz H, Yüce İ, Kaya E, Kekilli Ö, Ocaktan H, Topsakal M, Gürocak NY, Osanmaz H, Kılınç FM, Başkonuş T, Dumlupınar Z 2019. Characterization of M3 Mutants of Seri 82 Bread Wheat Cultivar Using Functional Markers. BSJ Agri 2(4): 194-202.

Koebner RMD 1995. Generation of PCR-Based Markers for The Detection of Rye Chromatin in A Wheat Background. Theoretical and Applied Genetics 90(5): 740-745.

Korzun V, Roder MS, Worland AJ, Borner A 1997. Intrachromosal Mapping of the Genes for Dwarfing (Rht12) and Vernelisation Response (Vrn1) in Wheat by Using RFLP and Microsatellite Markers. Plant Breeding 116: 227-232.

Leisova L, Kucera L, Dotlacil L 2007. Genetic Resources of Barley and Oat Characterized by Microsatellites. Czech J Genet Plant 43: 97-104.

Leisova L, Ovesna J 2001. The Use of Microsatellite Analysis for The Identification of Wheat Varieties. Czech J Genet Plant 116: 227-232.

Li YC, Fahima T, Peng JH, Roder MS, Kirzhner VM, Beiles A, Korol AB, Nevo E 2000. Edaphitic Microsatellite DNA Divergence in Wild Emmer Wheat, Triticum Dicoccoides, at A Microsite: Tabigha, Israel. Theoretical and Applied Genetics 101: 1029-1038.

Li Y, Wongprasert K, Shekhar M, Ryan J, Dierens L, Meadows J, Preston NP, Coman GJ, Lyons RE 2007. Development of Two Microsatellite Multiplex Systems for Black Tiger Shrimp Penaeus Monodon and Its Application in Genetic Diversity Study for Two Populations. Aquaculture 266: 279-288. 
Maryami Z, Fazeli A, Mehrabi AA 2014. Investigation of Diversity of Waxy-A1 Gene Using Amplification in Different Spices in A Genome Wheat's. Advances in Environmental Biology 8(7): 2004-2007.

Medini M, Hamze S, Rebai A, Baum M 2005. Analysis of Genetic Diversity in Tunisian Durum Wheat Cultivars and Related Wild Species by SSR and AFLP Markers. Genet Resour Crop Ev 52: 21-31.

Montilla-Bascon G, Sanchez-Martin J, Rispail N, Rubiales D, Mur L, Langdon T, Grifftihs I, Howarth C, Prats E 2013. Genetic Diversity and Population Structure among Oat Cultivars and Landraces. Plant Mol Biol Rep 31: 1305-1314.

Motawei MI, Al-Doss AA, Moustafa KA 2007. Genetic Diversity among Selected Wheat Lines Differing in Heat Tolerance Using Molecular Markers. Journal of Food, Agriculture \& Environment 5(1): 180-183.

Nersting LG, Andersen SB, Von Bothmer R, Gullord M, Jorgensen RB 2006. Morphological and Molecular Diversity of Nordic Oat through One Hundred Years of Breeding. Euphytica 150: 327337.

Oliver RE, Obert DE, Hu G, Bonman JM, O'LearyJepsen E, Jackson EW 2010. Development of OatBased Markers from Barley and Wheat Microsatellites. Genome 53(6): 458-471.

Özbek Ö 2006. Yabani Tetraploit Buğday Triticum turgidum var. dicoccoides (Körn. Schwein) Popülasyonlarında Genetik Çeşitliliğin Moleküler Markörler (AFLP, RFLP) ile Tespit Edilmesi, Gazi Üniversitesi Fen Bilimleri Enstitüsü, Doktora Tezi,
$123 \mathrm{~s}$.

Özcan B 2008. Kendilenmis Monoik Atlantik Sakızı Popülasyonunda Genetik Haritalama için Polimorfik Yöntem ve Markörlerin Belirlenmesi. Çukurova Üniversitesi Fen Bilimleri Enstitüsü Biyoteknoloji Anabilim Dalı, Yüksek Lisans Tezi, $68 \mathrm{~s}$.

Plaschke J, Ganal MW, Roder MS 1995. Detection of Genetic Diversity in Closely Related Bread Wheat Using Microsatellite Markers. Theoretical and Applied Genetics 91: 1001-1007.

Roder MS, Korzun V, Wendehake K, Plaschke J, Tixier M, Leroy P, Ganal MW 1998. A Microsatellite Map of Wheat. Genetics 149: 2007-2023.

Rohlf FJ 2005. NTSYS-Pc: Numerical Taxonomy and Multivariate Analysis System Version 2.2. Setauket, Exeter Publishing, New York, USA.

Roussel V, Leisova L, Exbrayat F, Stenho Z, BalFourier F 2005. SSR Allelic Diversity Changes in 480 European Bread Wheat Varieties Released from 1840 to 2000. Theoretical and Applied Genetics 111: 162-170.

Shariflou MR, Sharp PJ 1999. A Polymorphic Microsatellite in the 3'end of 'Waxy' genes of Wheat, Triticum Aestivum. Plant Breeding, 118: 275-277.

Weir BS 1996. Genetik Veri Analizi II, 2. Baskı. Sinauer Associates Inc, Sunderland, MA.

Yan L, Helguera M, Kato K, Fukuyama S, Sherman J, Dubcovsky J 2004. Allelic Variation at the VRN1 Promoter Region in Polyploid Wheat. Theoretical and Applied Genetics 109(8): 1677-1686. 